\title{
Three-dimensional Virtual Models of 3D-Scanned Real Cadaveric Samples Used as a Complementary Educational Resource for the Study of Human Anatomy: Undergraduate Student's Perception of this New Technology
}

\author{
Modelos Virtuales Tridimensionales de Muestras Cadavéricas Reales Obtenidas con Escáner 3D, \\ Utilizados como Recurso Educativo Complementario para el Estudio de la Anatomía Humana: \\ Percepción de los Estudiantes Universitarios Enfrentados a esta Nueva Tecnología
}

\author{
Gonzalo Tiznado-Matzner ${ }^{1}$; Sandra Bucarey-Arriagada ${ }^{1}$ \& Rodrigo Lizama Pérez $^{2}$
}

\begin{abstract}
TIZNADO-MATZNER, G.; BUCAREY-ARRIAGADA, S.; \& LIZAMA, P. R. Three-dimensional virtual models of 3D-scanned real cadaveric samples used as a complementary educational resource for the study of human anatomy: undergraduate student's perception of this new technology. Int. J. Morphol., 38(6):1686-1692, 2020.
\end{abstract}

SUMMARY: The emergence of the digital society in the 21 st century due to great advances in information and communication technologies (ICT) has allowed the development of research, communication, and collaboration activities related to knowledge and information. ICTs have influenced many aspects of society, especially educational work, and many educational establishments have adopted these technologies in a bid to enhance their teaching methods. One of the most representative cases is the global expansion of elearning platforms. Until now, the traditional method of study of human anatomy, a key component of any study plan in the health education area, has been mainly based on classic texts. However, different types of software made an appearance in this century such as the three-dimensional (3D) atlases consisting of digital illustrations of the human body. However, there might be a high cost of investment involved when purchasing these kind of software. This research aimed to study the perception of human anatomy students regarding the use of models of 3D-scanned real cadaveric samples available at http://anatomiahumana3d.com, as a complementary educational resource to conventional study. A satisfaction survey was designed which consisted of four items. The survey was answered by 134 students. The format of the models, functionality of the resource, content and teaching of the resource, and finally the general evaluation, reached 96.8 $\%, 84.05 \%, 81.14 \%$, and $89.4 \%$ of perception of satisfaction, respectively. The results show that the new generations of students are immersed in a technological environment, therefore, both general and anatomy teaching could benefit from the use of new technologies.

KEY WORDS: 3D anatomy; Anatomy education; 3D digital models; Open educational resources; ICT.

\section{INTRODUCTION}

The changes occurred in the society during the $21 \mathrm{st}$ century as a consequence of the major advance of technologies brought the emergence of the so-called digital society (Lévy, 2007), characterized by the dominant use of information and communication technologies (ICT) in activities such as research, communication, dissemination of knowledge and information, production, organization, and administration (Bustos \& Coll, 2010). ICTs have influenced many aspects of society and, especially, educational work therefore the Universities are adopting these technologies to enhance the teaching methods and speed up the process of appropriation of knowledge.
The rise of virtual education and the digital content produced by it placed the development of educational materials in the spotlight. Initially, it was the business organizations that made use of virtual education to train their employees in a more efficient way, especially those in either distant or different places, allowing them to use flexible methodologies to optimize the creation of educational materials in terms of time, design, and distribution (Astudillo et al., 2011).

The term learning objects (LO) was first used in 1992 by Wayne Hodgins, who was inspired by watching his

\footnotetext{
${ }^{1}$ Instituto de Anatomía, Histología y Patología, Facultad de Medicina. Universidad Austral de Chile, Valdivia, Chile.

${ }^{2}$ Departamento de Ciencias Morfológicas, Facultad de Medicina y Ciencia, Universidad San Sebastián, General Lagos 1163 , Valdivia 5090000, Chile.
} 
TIZNADO-MATZNER, G.; BUCAREY-ARRIAGADA, S.; \& LIZAMA, P. R. Three-dimensional virtual models of 3D-scanned real cadaveric samples used as a complementary educational resource for the study of human anatomy: undergraduate student's perception of this new technology. Int. J. Morphol., 38(6):1686-1692, 2020.

children play with $L E G O \circledR$ blocks and associated them with standardized learning blocks that could be reused in the educational process (Tovar et al., 2014).

In subsequent years, the concept of learning object underwent some changes and a definition had not yet been established universally so it varies depending on the author. According to Downes (2001), LOs are educational tools that use ICT to achieve content that is both friendly and valuable for the people who use it. Mason \& Rehak (2003) stated that LOs cannot be created as another isolated information resource, instead, they should be thought of as resources with specific attributes for their interaction in an e-learning environment, easy to locate, use, store, and share. To accomplish all this, these resources must be:

Reusable. The resource must be modular to serve as the basis or component of another resource. It must also have the necessary technology, structure, and components to be included in various applications.

Accessible. They can be indexed for more efficient location and retrieval, using standard metadata schemas.

Interoperable. They can operate between different hardware and software platforms.

Portable. They can be moved and housed on different platforms transparently, without any change in structure or content.

Durable. Must remain intact to software and hardware upgrades.

These attributes give meaning to the promises of LOs as units that will facilitate the development and global expansion of e-learning. The modularity that should characterize them increases versatility and functionality, obtaining more resources available and distributed in different systems that can communicate to share efforts and results. LO creation is not easy, but the effort and costs involved in their production are balanced with the number of times the resource can be reused.

Technology in the teaching-learning of Human Anatomy. Human anatomy is a key component in any curriculum of the health education area and is considered the cornerstone of good clinical practice regardless of the final specialty. It is universally established as fundamental since it helps to acquire the skills to perform a correct clinical examination, interpretation of medical images, and intervention techniques (Petriceks, et al., 2018).
A key element in the learning of anatomy and other sciences is to build mental models of anatomical structures and understand the spatial relationships between each other (Aziz et al., 2002; Turney, 2007; Sugand et al., 2010).

Advances in computer systems to model the body have made of digital representations a helpful resource in the learning process (Gabard et al., 2012). Biomedical illustrators can now create accurate three-dimensional digital models from patient computed tomography (CT) data (Corl et al., 2000; Park et al., 2006).

Despite the importance of human anatomy, as highlighted by different articles, health school curricula have been under constant pressure, for many years, to deliver more information in less time. This has caused many schools to have the obligation to reduce the theoretical and laboratory hours, particularly in macroscopic anatomy classes (Moxham \& Plaisant, 2007; Yeung et al., 2012).

Another important aspect is that the development of the reading skills of the students must have reached an appropriate level by the time they reach higher education. However, and with increasing frequency, higher education institutions have noticed the difficulties of their students to understand what they read (Rubilar et al., 2010; Makuc, 2011; Maldonado Fuentes et al., 2012; Wigfield et al., 2015). This is critical in the health education area, where students are confronted with texts containing two-dimensional (2D) images and extensive descriptions that can lead to discouragement, especially if they have not understood the theoretical or practical classes.

In this context, the attitude that those of us who teach must have, in the face of these changes, should involve a much more practical and active approach, ensuring that the student is able to understand the structures reviewed in the theoretical classes to later appreciate them in their three dimensions during the practical lessons. The students have a set time for this activity which is relatively short, because the laboratories have a maximum capacity that often exceeds due to the ever increasing number of students each year, who must be divided into groups.

Another issue is the increasingly scarce donation of corpses, resulting in researchers having to request them from other countries (Habicht et al., 2018). Due to this shortage, the corpses end up being used for a long time, with the consequent deterioration of the samples over the years until, finally, some structures become unrecognizable (TiznadoMatzner et al., 2019a). One of the solutions to this problem is to store the samples through plastination, which is a technical procedure for biological preservation created by 
TIZNADO-MATZNER, G.; BUCAREY-ARRIAGADA, S.; \& LIZAMA, P. R. Three-dimensional virtual models of 3D-scanned real cadaveric samples used as a complementary educational resource for the study of human anatomy: undergraduate student's perception of this new technology. Int. J. Morphol., 38(6):1686-1692, 2020.

doctor and anatomist Gunther von Hagen. It consists of extracting body fluids, e.g. water and lipids, using solvents such as acetone and then replacing them with different types of resins (Weiglein, 2002). Another new option is to keep the samples as $3 \mathrm{D}$ virtual models which are scans from all angles of the cadaveric structures. These can be observed in their different dimensions through electronic devices such as cell phones, tablets, and computers from anywhere in the world provided that there is an internet connection available. The three-dimensional visualization of these virtual samples could offer a better mental representation of their form and organization which, in turn, would favor effective student learning (Petriceks, et al.).

The aim of this work is to measure the level of satisfaction generated by the models of 3D-scanned real cadaveric samples, as a complementary method to the traditional study of human anatomy for the students undertaking this subject.

\section{MATERIAL AND METHOD}

At the beginning of the second semester of 2018, the careers offering the module of human anatomy within its curriculum were identified and the results were: Pedagogy in Physical Education and Recreation, Kinesiology, Medicine, Medical Technology, and Occupational Therapy. The students were asked if, in addition to using the bibliography suggested in the program of each career, they would voluntarily use the 3D-scanned human cadaveric samples availableathttp://anatomiahumana3d.com(Spanishversion) or http://3dhumananatomy.org (English version) as a complementary method of study. These online resources were chosen because they are open web platforms, therefore any student can enter without having to create an account or pay a subscription. This process was previously described by Tiznado-Matzner et al. (2019b). At the time of the investigation, the site had 96 samples. Each sample showed the detailed structures, named in Spanish and English, using the International Anatomical Terminology.

A survey was developed based on Bucarey \& Álvarez (2006) to measure the level of satisfaction using the 3D-scanned human cadaveric samples as a complementary study tool to the use of bibliography suggested in the program of each career.

The survey consisted of the following 4 items: a) format of the resource, b) functionality of the resource, c) content and learning of the resource and d) general

Table I. The survey consisted of 24 questions in total, divided in 4 items to measure: a) Resource Format, b) Resource Functionality, c) Content and Learning about the Resource, and d) General Evaluation.

\begin{tabular}{ll}
\hline a) & Resource Format \\
\hline 1 & The letter size allows a comfortable reading of the content. \\
2 & The color of the text makes reading easier. \\
3 & The images on the home page clearly show the picture content. \\
4 & The images on the home page have the appropriate size for best readab \\
5 & The images on the home page show a sharp resolution. \\
6 & 3D models have a sharp resolution. \\
7 & 3D models show appropriate colors. \\
8 & 3D models have suitable brightness. \\
9 & 3D models, like OER, show good quality. \\
10 & 3D models have a suitable size. \\
\hline b) & Resource Functionality \\
\hline 11 & It is easy to use. \\
12 & It is easy to go back to the former section. \\
13 & It is easy to go back to the home page. \\
14 & It allows freedom to go to the selected section. \\
15 & Each 3D model took less than a minute to open. \\
16 & Each 3D model took more than five minutes to open. \\
\hline c) & Content and Learning about the Resource \\
\hline 17 & Content represents what is offered in the resource. \\
18 & It made it easier for me to understand thesubject. \\
19 & It helped me to solve doubts. \\
20 & The content is well organized on the webpage. \\
\hline 21 & The learning process is faster with this resource. \\
\hline 22 & General Evaluation \\
\hline
\end{tabular}$\quad \begin{aligned} & \text { I liked it. } \\
& \end{aligned}$


TIZNADO-MATZNER, G.; BUCAREY-ARRIAGADA, S.; \& LIZAMA, P. R. Three-dimensional virtual models of 3D-scanned real cadaveric samples used as a complementary educational resource for the study of human anatomy: undergraduate student's perception of this new technology. Int. J. Morphol., 38(6):1686-1692, 2020.

evaluation of the resource. The total number of questions applied was 24 (Table I), with each one presenting four response options according to the perception of the student: excellent, very good, insufficient, and deficient. The survey was designed using the Google Drive tool and was sent out to the students of the 5 careers at the end of the semester to be answered voluntarily. The survey was answered by 139 students.

\section{RESULTS}

In all the items the survey showed that the designed webplatform and the 3D models were well received, assuming that the options of excellent and very good referred to satisfaction in the use of the educational resource, while insufficient and deficient referred to dissatisfaction in the use of the educational resource.

\section{Resource Format}

\section{Deficient $\square$ Insufficient $\square$ Very good $\square$ Excellent}

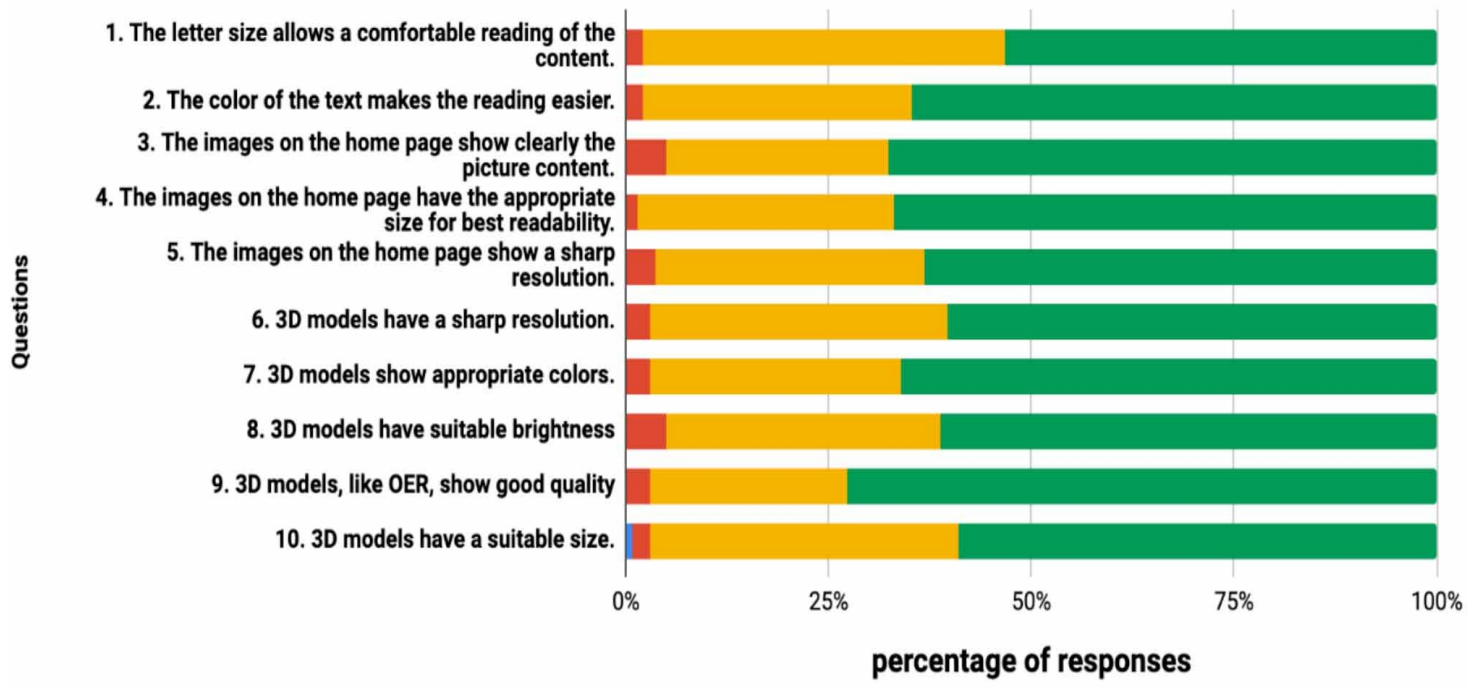

Fig. 1. Level of students satisfaction, $63.5 \%$ excellent; $33.3 \%$ very good; $3 \%$ insufficient, and $0.007 \%$ deficient.

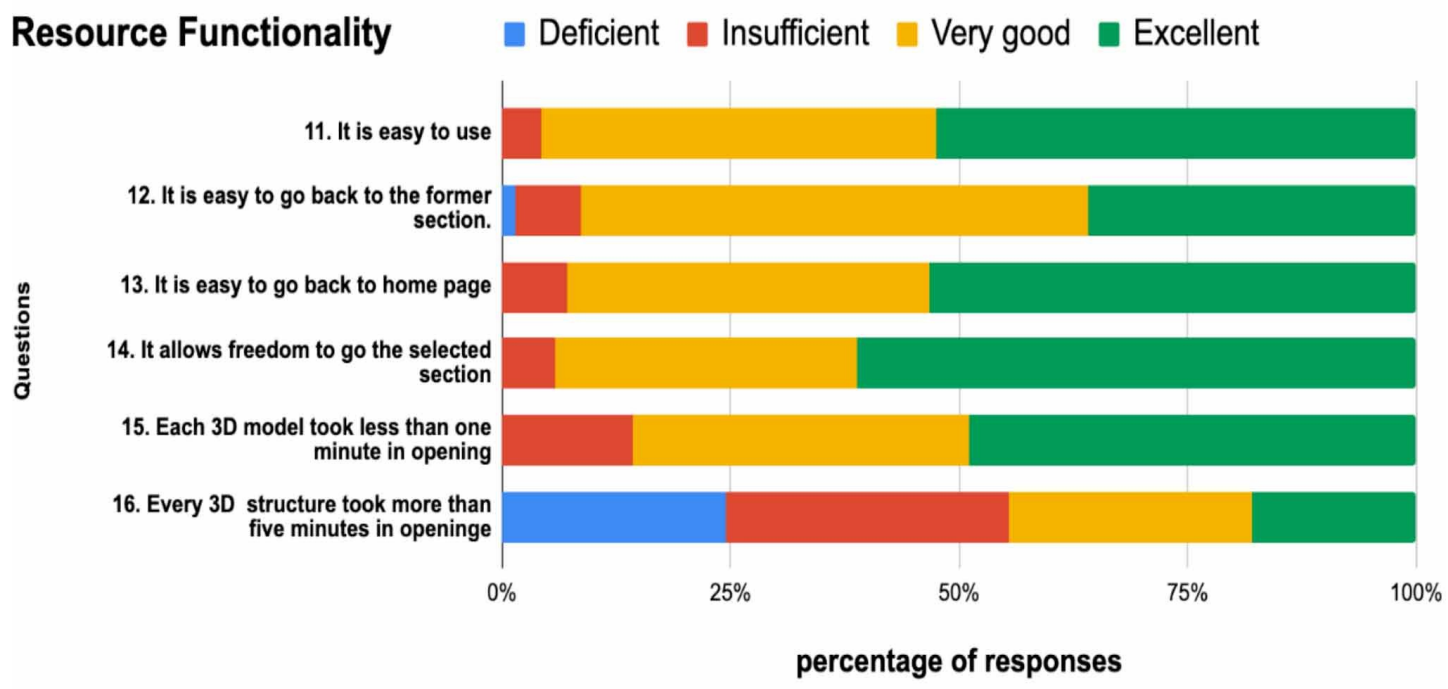

Fig. 2. Level of students satisfaction, $44.96 \%$ excellent; $39.09 \%$ very good; $11.63 \%$ insufficient, and $4.31 \%$ deficient.

The first item, related to the resource format, obtained a satisfactionlevel of $96.8 \%$ (Fig. 1). The second item referred to the functionality of the resource and registered a satisfaction level of $84.05 \%$ (Fig. 2). In the case of the third item, which referred to the content and teaching of the resource, a satisfaction level of $81.14 \%$ was reached (Fig. 3). Finally, the fourth item, which measured the general evaluation of the resource, obtained $89.4 \%$ of student satisfaction (Fig. 4). 


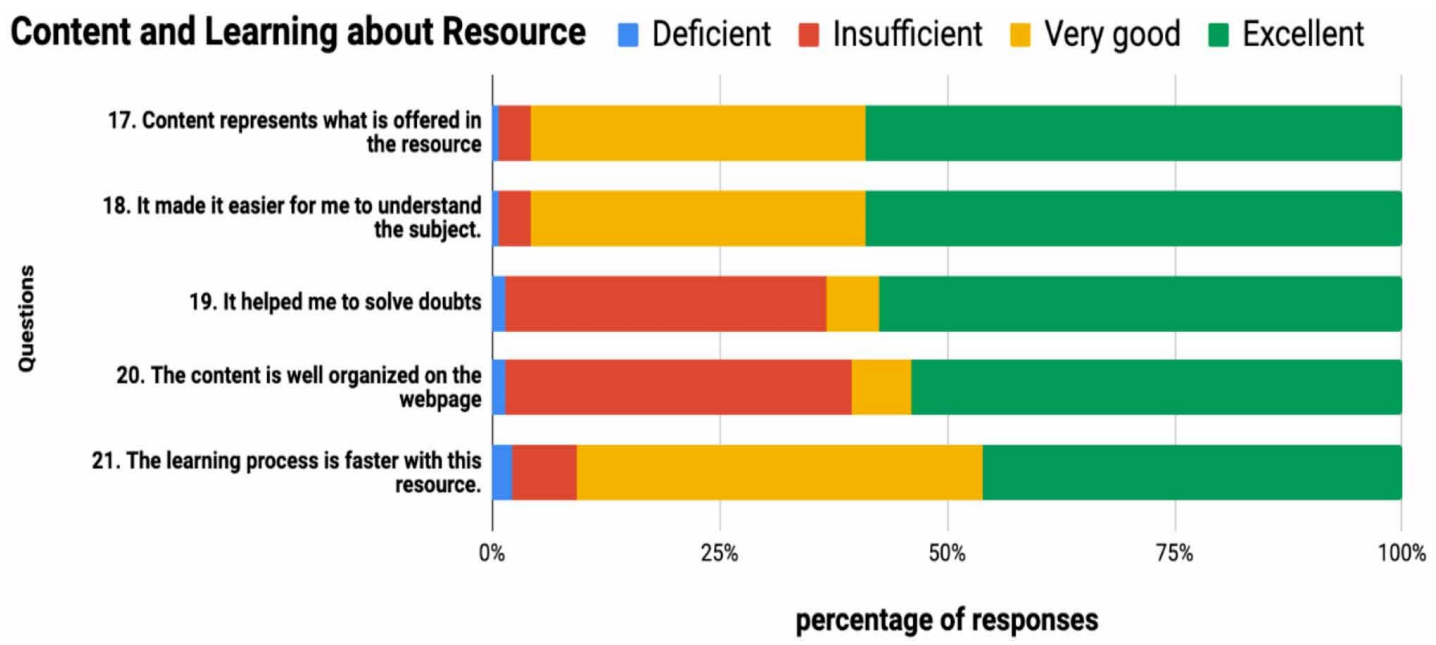

Fig. 3. Level of students satisfaction, $55.1 \%$ excellent; $26.04 \%$ very good; $17.5 \%$ insufficient, and $1.3 \%$ deficient.

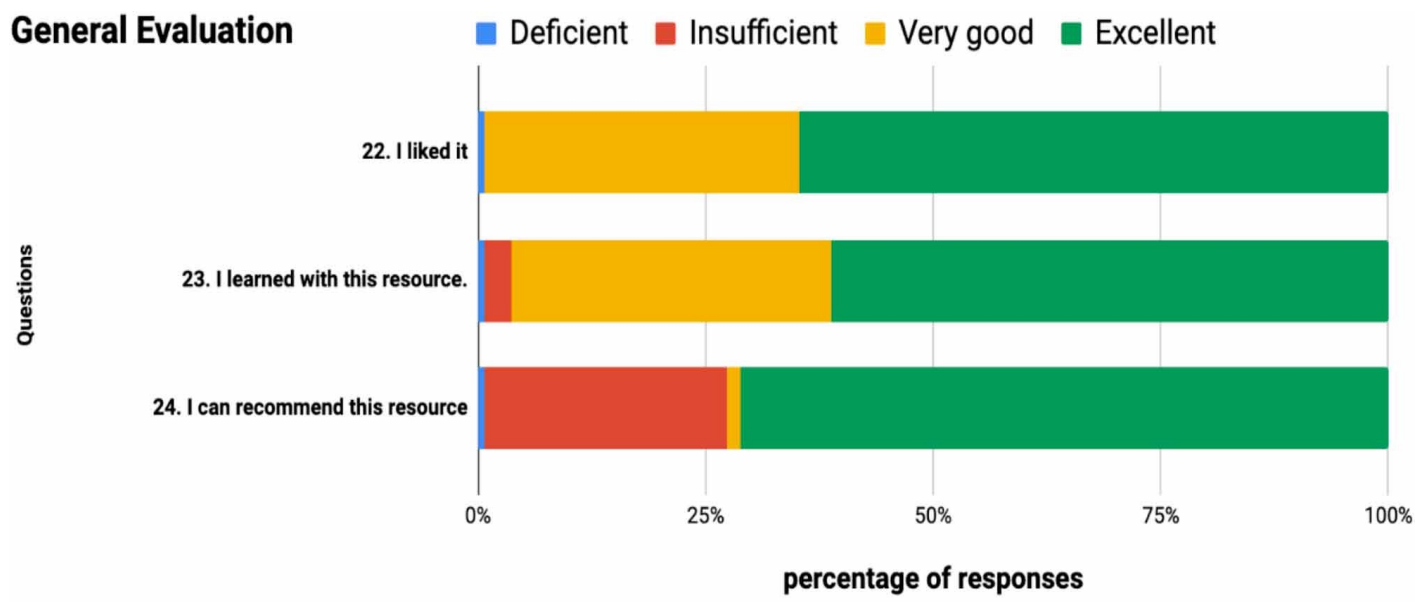

Fig. 4. Level of students satisfaction, $65.7 \%$ excellent; $23.7 \%$ very good; $9.8 \%$ insufficient, and $0.72 \%$ deficient.

\section{DISCUSSION}

The survey showed that the students were most keen to use learning objects such as 3D-scanned samples of human corpses. In the four items of the survey it could be observed that more than $80 \%$ of the student's responses varied between excellent or very good. The only point showing certain deficiencies was related to the time it took to open certain models. However, this is mainly due to the quality of the internet connection in use, since the size of models can vary from $1 \mathrm{MB}$ to $10 \mathrm{MB}$ depending on the complexity of the structures. These models are hosted on a web platform, they do not require a password and they are free of charge, allowing access to anyone in the world with an internet connection.
The use of cadavers to teach human anatomy is well established but the financial, ethical, and supervisory limitations on the use of body-fixing and preservative substances are the main reasons behind the introduction of new teaching methodologies (Moro et al., 2017). In this digital era, many educational establishments are still following the traditional way of teaching anatomy, that is, theoretical classes with anatomical structures being projected mainly using 2D images and, to a lesser extent, using videos that describe the morphology of a particular structure, to finally use the laboratories where the students can observe real or replica corpses to validate the knowledge acquired in the theoretical classes (Cárdenas-Valenzuela, 2019). 
TIZNADO-MATZNER, G.; BUCAREY-ARRIAGADA, S.; \& LIZAMA, P. R. Three-dimensional virtual models of 3D-scanned real cadaveric samples used as a complementary educational resource for the study of human anatomy: undergraduate student's perception of this new technology. Int. J. Morphol., 38(6):1686-1692, 2020.

Codd \& Choudhury (2011) designed a 3D model of the anterior compartment of the forearm, with the purpose of evaluating the use of $3 \mathrm{D}$ virtual reality compared to traditional teaching methods. They found no significant variation in the scores between the group that used only cadaver anatomy and dissection books and the group that only worked with the electronic resource. However, the comments of all users regarding the electronic resource were positive. Something similar was reported by Park et al. (2019) who compared commercial software such as Visual Body ${ }^{\circledR}$ and Essential Anatomy ${ }^{\circledR}$ from 3DMedial.com with the classic texts. These authors found that $3 \mathrm{D}$ atlases showed significantly high results on simple laboratory test questions. However, they indicated that they should be complemented with the deeper anatomical knowledge provided by the classic texts, giving this type of virtual systems a complementary function. Moro et al. used three types of technologies to assess the learning of anatomy. They used augmented reality devices and virtual reality glasses that allow learning through immersive experiences within a virtual field, and evaluated whether this type of technology is as effective as tablet-based applications and whether these methods allowed for better learning, participation, and student performance. They found no significant differences in the average of the evaluation scores, but they did find that some participants wearing virtual reality glasses had adverse effects like blurred vision, dizziness, or headache. Finally, they concluded that all three technologies were valuable for the teaching of anatomy and have other benefits such as greater student engagement. Over time, other researchers have noticed the advantages of working with educational complements such as virtual 3D models, especially when teaching about complex structures like the head and neck anatomy (Yeung et al., 2011; Brewer et al., 2012; De Ribaupierre \& Wilson, 2012; Pedersen et al., 2013), the ventricular system (Adams \& Wilson, 2011) and cerebral vascularization (Petersson et al., 2009; Nowinski et al., 2012).

In our study, we used the websites http:// anatomiahumana3d.com and http://3dhumanatomy.org because they have mainly $3 \mathrm{D}$ virtual models obtained through the scanning of real cadaveric samples, which makes a difference when compared to most of the software currently on the market or those designed by researchers or illustrators, as previously mentioned. We found that the perception of students of the use of new technologies to complement the study of anatomy with 3D models is remarkable, and it generates a greater commitment to study. It must be mentioned that recent authors (Adams \& Wilson; Pujol et al., 2016; Lee \& Park, 2018; Samim et al., 2019) have been developing 3D models which they often use for printing, to do this they use of images obtained from computerized axial tomography and magnetic resonance imaging, a technique that could help to make 3D models of living people and of healthy or pathological tissues.

\section{CONCLUSIONS}

The new generations of students are immersed in the use of technological tools, therefore, reading a book is often tedious for them. The study of human anatomy must be accompanied by technological elements that complement the study of classic books. For this reason, the results of the evaluation of 3D models of real human parts by the students undertaking the anatomy module as part of their courses showed it was a widely accepted resource and those students also requested more tools and samples to further improve their knowledge.

TIZNADO-MATZNER, G.; BUCAREY-ARRIAGADA, S.; \&

LIZAMA, P. R. Modelos virtuales tridimensionales de muestras cadavéricas reales obtenidas con escáner $3 \mathrm{~d}$, utilizados como recurso educativo complementario para el estudio de la anatomía humana:percepción de los estudiantes universitarios enfrentados a esta nueva tecnología. Int. J. Morphol., 38(6):1686-1692, 2020.

RESUMEN: El comienzo de la sociedad digital en el siglo XXI debido a los grandes avances en las tecnologías de la información y comunicación (TIC) ha permitido el desarrollo de actividades de investigación, comunicación y colaboración relacionadas con el conocimiento y la información. Las TIC han influido en muchos aspectos de la sociedad, especialmente en el trabajo educativo, y muchos establecimientos educativos han adoptado estas tecnologías en un intento por mejorar sus métodos de enseñanza. Uno de los casos más representativos es la expansión global de las plataformas de e-learning. Hasta ahora, el método tradicional de estudio de la anatomía humana, componente clave de cualquier plan de estudios en el área de educación para la salud, se ha basado principalmente en textos clásicos. Sin embargo, en este siglo aparecieron diferentes tipos de software, como los atlas tridimensionales (3D) que consisten en ilustraciones digitales del cuerpo humano. Sin embargo, puede haber un alto costo de inversión involucrado al adquirir este tipo de software. Esta investigación tuvo como objetivo estudiar la percepción de los estudiantes de anatomía humana sobre el uso de modelos de muestras de cadáveres reales escaneados en 3D disponibles en http://anatomiahumana3d.com, como recurso educativo complementario al estudio convencional. Se diseñó una encuesta de satisfacción que constaba de cuatro ítems. La encuesta fue respondida por 134 estudiantes. El formato de los modelos, funcionalidad del recurso, contenido y didáctica del recurso, y finalmente la evaluación general, alcanzaron el 96,8 \%, 84,05\%, 81,14\% y $89,4 \%$ de percepción de satisfacción, respectivamente. Los resultados muestran que las nuevas generaciones de estudiantes se encuentran inmersas en un entorno tecnológico, por lo que tanto la enseñanza general como la de anatomía podrían beneficiarse del uso de las nuevas tecnologías.

PALABRAS CLAVE: Anatomía 3D; Educación en anatomía; Modelos digitales 3D; Recursos educativos abiertos; TIC. 
TIZNADO-MATZNER, G.; BUCAREY-ARRIAGADA, S.; \& LIZAMA, P. R. Three-dimensional virtual models of 3D-scanned real cadaveric samples used as a complementary educational resource for the study of human anatomy: undergraduate student's perception of this new technology. Int. J. Morphol., 38(6):1686-1692, 2020.

\section{REFERENCES}

Adams, C. M. \& Wilson, T. D. Virtual cerebral ventricular system: An MRbased three-dimensional computer model. Anat. Sci. Educ., 4(6):340-7, 2011.

Astudillo, G. J; Sanz, C. \& Willging, P. Análisis del Estado del Arte de los Objetos de Aprendizaje. La Plata, Repositorio Institucional de la Universidad Nacional de la Plata, 2011.

Aziz, M. A.; McKenzie, J. C.; Wilson, J. S.; Cowie, R. J.; Ayeni, S. A. \& Dunn, B. K. The human cadaver in the age of biomedical informatics. Anat. Rec., 269(1):20-32, 2002.

Brewer, D. N.; Wilson, T. D.; Eagleson, R. \& De Ribaupierre, S. Evaluation of neuroanatomical training using a $3 \mathrm{D}$ visual reality model. Stud. Health Technol. Inform., 173:85-91, 2012.

Bucarey, S. \& Álvarez, L. Methodology to construct learning object for teaching human anatomy in integrated courses. Int. J. Morphol., 24(3):357-62, 2006.

Bustos, A. \& Coll, C. Los entornos virtuales como espacios de enseñanza y aprendizaje. Una perspectiva psicoeducativa para su caracterización y análisis. Rev. Mex. Investig. Educ., 15(44):163-84, 2010.

Cárdenas-Valenzuela, J. L. Teaching of anatomy. Use of media in the classroom. Int. J. Morphol., 37(3):1123-9, 2019.

Codd, A. M. \& Choudhury, B. Virtual reality anatomy: is it comparable with traditional methods in the teaching of human forearm musculoskeletal anatomy? Anat. Sci. Educ., 4(3):119-25, 2011.

Corl, F. M; Garland, M. R. \& Fishman, E. K. Role of computer technology in medical illustration. AJR Am. J. Roentgenol., 175(6):1519-24, 2000.

De Ribaupierre, S. \& Wilson, T. D. Construction of a 3-D anatomical model for teaching temporal lobectomy. Comput. Biol. Med., 42(6):692-6, 2012.

Downes, S. Learning objects: resources for distance education worldwide. Int. Rev. Res. Open Distrib. Learn., 2(1), 2001. DOI: https://www.doi.org/ 10.19173/irrodl.v2i1.32

Gabard, D. L; Lowe, D. L. \& Chang, J. W. Current and future instructional methods and influencing factors in anatomy instruction in physical therapy and medical schools in the US. J. Allied Health, 41(2):53-62, 2012.

Habicht, J. L.; Kiessling, C. \& Winkelmann, A. Bodies for anatomy education in medical schools: an overview of the sources of cadavers worldwide. Acad. Med., 93(9):1293-300, 2018.

Lee, S. E. \& Park, J. S. Automatic 3D modeling of liver segments including segmental branches of portal triad and hepatic vein based on the sectionedimages. Int. J. Morphol., 36(2):402-6, 2018.

Lévy, P. Ciberculura: la Cultura en la Sociedad Digital. Ciudad de México, ANTHROPOS, 2007.

Makuc, M. The implicit theories about text comprehension and the reading competency of the first year students at Universidad de Magallanes. Estud. Pedagóg., 37(1):237-54, 2011.

Maldonado Fuentes, A. C.; Sandoval Rubilar, P. \& Rodriguez Alveal, F. Spanish reading comprehension levels among primary school teacher education BA program students. Folios, 35:33-47, 2012.

Mason, R. \& Rehak, D. Keeping the Learning in Learning Objects. In: Littlejohn, A. (Ed.). Reusing Online Resources: A Sustainable Approach to E-Learning. London, Kogan Page, 2003. pp.20-34.

Moro, C.; S`tromberga, Z.; Raikos, A. \& Stirling, A. The effectiveness of virtual and augmented reality in health sciences and medical anatomy. Anat. Sci. Educ., 10(6):549-59, 2017.

Moxham, B. J. \& Plaisant, O. Perception of medical students towards the clinical relevance of anatomy. Clin. Anat., 20(5):560-4, 2007.

Nowinski, W.L.; Johnson, A.; Chua, B. C. \& Nowinska, N. G. Three-dimensional interactive and stereotactic atlas of the cranial nerves and their nuclei correlated with surface neuroanatomy, vasculature and magnetic resonance imaging. J. Neurosci. Methods, 206(2):205-16, 2012.

Park, J. S.; Chung, M. S.; Hwang, S. B.; Shin, B. S. \& Park, H. S. Visible Korean Human: its techniques and applications. Clin. Anat., 19(3):216-224, 2006.

Park, S.; Kim, Y.; Park, S. \& Shin, J. A. The impacts of three-dimensional anatomical atlas on learning anatomy. Anat. Cell Biol., 52(1):76-81, 2019.

Pedersen, K.; Wilson, T. D. \& De Ribaupierre, S. An interactive program to conceptualize the anatomy of the internal brainstem in 3D. Stud. Health Technol. Inform., 184:319-23, 2013.
Petersson, H.; Sinkvist, D.; Wang, C. \& Smedby, O. Web-based interactive 3D visualization as a tool for improved anatomy learning. Anat. Sci. Educ., 2(2):61$8,2009$.

Petriceks, A. H.; Peterson, A. S.; Angeles, M.; Brown, W. P. \& Srivastava, S. Photogrammetry of human specimens: an innovation in Anatomy education. J. Med. Educ. Curric. Dev., 5:1-10, 2018.

Pujol, S.; Baldwin, M.; Nassiri, J.; Kikins, R. \& Shaffer, K. Using 3D modeling techniques to enhance teaching of difficult anatomical concepts. Acad. Radiol., 23(4):507-16, 2016.

Rubilar, S. P. R.; Carrillo, F. M.; Fuentes, M. A. C. \& Alveal, R. F. Math reasoning and reading comprehension skills assessment of entrant students from the primary school teaching program: a comparative study in two universities of the Council of Rectors (CRUCH). Educ. Rev., 2:73-102, 2010.

Samim, M.; Eftekhary, N.; Vigdorchik, J. M.; Elbuluk, A.; Davidovitch, R.; Youm, T. \& Gyftopoulos, S. 3D-MRI versus 3D-CT in the evaluation of osseous anatomy in femoroacetabular impingement using dixon 3D FLASH sequence. Skeletal. Radiol., 48(3):429-36, 2019.

Sugand, K.; Abrahams, P.\& Khurana, A. The anatomy of anatomy: a review for its modernization. Anat. Sci. Educ., 3(2):83-93, 2010.

Tiznado-Matzner, G.; Bucarey-Arriagada, S. \& Aravena, P. C. Journey through the reality of human anatomy laboratories of 12 Chilean universities. Int. J. Morphol., 37(1):17-21, 2019a.

Tiznado-Matzner, G.; Bucarey-Arriagada, S. \& Lizama-Pérez, R. Experience in the creation of an online platform to host three-dimensional models of real anatomical pieces to be shared as Open Educational Resources (OER). Int. J. Morphol., 37(4):1267-71, 2019b.

Tovar, L; Bohórquez, J. \& Puello, P. Propuesta metodológica para la construcción de objetos virtuales de aprendizaje basados en realidad aumentada. Form. Univ., 7(2):11-20, 2014.

Turney, B. W.Anatomy in a modernmedicalcurriculum. Ann. R.Coll. Surg.Engl., 89(2):104-7, 2007.

Weiglein, A. H. Preservation and plastination. Clin. Anat., 15(6):445, 2002

Wigfield,A.; Eccles, J.S.;Fredricks, J.A.;Simpkins, S.;Roeser, R.W.\&Schiefele, U. Development of achievement motivation and engagement. 7 th ed. New York, John Wiley \& Sons, 2015.

Yeung, J. C.; Fung, K. \& Wilson, T. D. Development of a computer-assisted cranial nerve simulation from the visible human dataset. Anat. Sci. Educ,. 4(2):92-7, 2011.

Yeung, J. C.; Fung, K. \& Wilson, T. D. Prospective evaluation of a web-based three-dimensional cranial nerve simulation. J. Otolaryngol. Head Neck Surg., 41(6):426-36, 2012.

\section{Corresponding author: \\ Gonzalo Tiznado Matzner \\ Universidad Austral de Chile. \\ Campus Isla Teja S/N \\ Valdivia \\ CHILE}

Email: gonzalo.tiznado@uach.cl

Received: 08-06-2020

Accepted: 10-08-2020 